\title{
Business Analysis Of Village-Owned Enterprises (Bumdes): A Poverty Reduction Strategy (Case Study Kuala Sub-District, Nagan Raya Regency)
}

\author{
Ar Royyan Ramly ${ }^{1}$,Wahyuddin ${ }^{2}$, Jullimursyida $^{3}$, Mawardati $^{4}$ \\ $\{\underline{1}$ arroyyanramly@serambimekkah.ac.id $\}$ \\ 1,2 Departement Islamic Studies,Universitas Serambi Mekkah, Aceh, Indonesia \\ . ${ }^{3,4}$ Departement Management and Agriculture, Universitas Malikulsaleh, Aceh, Indonesia
}

\begin{abstract}
This paper aims to analyze and observe several businesses of village-owned enterprises (BUMDes) by utilizing the local potential in Kuala Nagan Raya Regency. The urgency of this research leads to the empowerment of rural communities and also the increase of BUMDes' income which is directed at reducing poverty in the village. The sample in this study took as many as 8 villages from 17 villages in Kuala Subdistrict. The data collection technique of the researcher did with interview style, Focuss Group Discussion (FGD) and observation. The method of analysis in this study uses SWOT analysis to see the business efficiency of each BUMDes in Kuala Sub-District. The results showed that out of the nine BUMDes in Kuala Sub-district there were still weaknesses in financial management and village original income (PADes). However, the strengths and opportunities possessed by BUMdes in each village area have a lot of local potential that can be utilized by BUMDes business units, and community participation in supporting the role of BUMDes is still minimal compared to some villages in Nagan Raya district. Then there is no BUMDes strategy or model that can alleviate poverty directly in the district of Kuala. This is because there are still many new Bumdes in Kuala Sub-district.
\end{abstract}

Keywords: SWOT, Village Owned Enterprises, Poverty, Nagan Raya Regency.

\section{Introduction}

The village is a legal community unit that has a regional boundary that is authorized to regulate and administer government affairs, the interests of the local community based on community initiatives. The term village is often synonymous with poor, traditional and conservative communities (Misbahul and Jatmiko, 2012). Even though the development of the village has been long enough but until now there are still problems faced by the village and require immediate resolution, such as the low issue of the ability of human resources, the administration that is not in line [1]including the problem of poverty which is always a problem the main development of the village [2].

The government has given special attention to village development. One of them is the enactment of Law Number 6 of 2014 concerning Villages. This law is very helpful for the village government in its management and is considered to make it easier to implement village 
governance due to more detailed rules. Rahmawati explained in her research that the village was ready in implementing the Law Number 6 of 2014 concerning Villages Previously, village financial management was based on Law No. 32 of 2004 concerning Regional Government and is part of regional finance (Rahmawati, 2015).

Village-owned business entities are established on the basis of decisions on strategies to reduce poverty directly to very poor communities in the Aceh region. according to data from the Statistics Center (BPS) in 2016-2018 the poverty rate in Aceh increased by $15.4 \%$ greater than the national average. Therefore, there is a need for serious handling of poverty in Aceh, the greater the poverty gap, the further the welfare line is felt by the community.

The existence of a Village Owned Enterprise (BUMDes) aims to strengthen the village economy, because the capital owned by the village through direct participation from village wealth [3]. BUMDes is also a local economic empowerment tool with various types of potential that exist in the village, also must be the backbone of the village government economy in order to achieve improved welfare of its citizens [4]. Through BUMDes, every village has the authority to expand the business according to local resources, the presence of BUMDes can hasten the independence of each village in the economic field. If each village is independent, then automatically we have created a village that is economically independent [5].Unlike the case in Nagan Raya district, with the wealth of potential villages owned such as, agriculture, plantations, livestock and small industries. However, the management of BUMDes in Nagan Raya district has not been maximized [2]. The main cause is the mapping of local potential that is not evenly distributed, only a part of the region that looks potential so that it gets empowerment from the economic sector both from the local and provincial governments. This is also strengthened by weak cultural conditions for village fund management, lack of adequate Human Resources (HR), lack of village manager skills, lack of business assistance, very small capital access, not supported by good facilities, also community behavior less participatory in the village. So that the chain of community poverty is never complete and very far from the word prosperity, as evidenced by the poverty rate in 2016 as many as 30,310 people or $19.25 \%$ and increased in 2017 by 30,060 people or $19.34 \%$ [6]To answer this problem, it is important and urgent to conduct a scientific study on the empowerment of BUMDes based on local potential in order to realize an independent village through maximizing the potential of the village.

Research on village economic empowerment has been investigated by [7] and [8], explaining that in order to improve rural economy, businesses must be based on the potential of the village. Specifically [9], [10], [11], [12] and [13], stated that the concept of social enterprise is a social mission for those who do business both in the city and in village. One of the social forms carried out is giving donations (charity) to the poor and weak groups. With the aim of fulfilling the basic needs of the poor, this will be realized with the support of the readiness of the human resource management of BUMDes which is adequate [14].

As far as the author's observation there is no single research on the empowerment of BUMDes based on local potential in order to realize an independent village in Kuala District, Nagan Raya District. This study wants to fill the gap of previous research by becoming a pioneering research in realizing the welfare of independent communities and villages through Local Potential-based Business Strategy analysis of BUMDes, village economic products, types of businesses and local wisdom. Thus we need to formulate the problem, as follows:

1. How far are BUMDes utilizing local potential in their business activities in the district of Nagan Raya district?

2. How is community participation in the activities of BUMDes in Kec, Kuala, Nagan Raya Regency?

3. How the empowerment of local potential-based BUMdes in the district Kuala Nagan Raya District? 
The expected results of this research are the formation of Bumdes business model in utilizing local potential to reduce poverty as a material consideration of the government, provincial government, district government and village government in the context of implementing village development to realize an independent village.

\section{Methodology}

Village-owned business entities are established on the basis of decisions on strategies to reduce poverty directly to the poor. As in the Aceh region, according to data from the Central Statistics Agency (BPS) in 2016-2017 the poverty rate in Aceh increased by $15.4 \%$ greater than the national average. While the percentage of poverty level of BPS of Nagan Raya Regency experienced an increase in Poverty in 2017 amounting to $19.34 \%$, increasing from 2016 at 19.25 Therefore, it needs serious handling of poverty in Aceh, the greater the poverty gap, the further welfare line that is felt by the community. So to reduce this gap, there needs to be a new program and model that is carried out by the community (bottom-up) or governmentdirected (top-down) in managing BUMDes business.

Village development can be improved through the development of the village's economic potential and become a joint place for rural communities to develop themselves and their environment independently and participatively. The existence of a Village-Owned Enterprise (BUMDesa) is one of the considerations to channel the initiative of the village community, develop the potential of the village, manage and utilize the potential of village natural resources, optimize human resources (villagers) in its management, and the presence of capital from the village government in the form of financing and village wealth that is submitted to be managed as part of BUMDes. The ideal BUMDes can become the axis of the life of the Village community. Because he stands or exists to fulfill the needs of the community, is able to absorb the production capacity of the community, and access is open to all villagers from various elements.To realize an independent village, a source of income is needed for the village from the village. The independence in question is the process carried out by the village government with the community to carry out activities in order to fulfill their needs according to their capabilities. Business units that move in the village must have distinctive features and competitive advantages so that they can make a significant contribution to improving the welfare of rural communities.

So far, the BUMDes empowerment program and model have been offered and worked on by the village government, but at the moment BUMDEs have not been fully successful. Even though the role of the Village-Owned Enterprise (BUMDes) is very important for the village in increasing the village's original income. Like Ponggok village in Klaten, Central Java and Ponjong village, Gunung Kidul Regency, Yogyakarta managed to run the village business unit through the utilization of local potential in the area, so that the village of Ponggok became an example of a tourist village that successfully empowered village-owned enterprises. Unfortunately, some regions, including Nagan Raya, have not been able to utilize local potential for four years. Meanwhile, according to [2], potential contained in the area is very large, such as plantations amounting to 42 percent of the total agricultural area by 30 percent, the local industry by 20 percent and the existing small businesses by 8 percent.

Therefore, it becomes a big question why with tremendous local potential, villages through BUMDes have not been able to manage this potential so that it becomes an economic source for the village and the welfare of the community. BUMDesa is expected to be able to stimulate and drive the economy in the countryside. Economic assets in the village must be managed entirely by the village community. BUMDes will move in tune with efforts to increase village 
original sources of income, mobilizing community economic activities. Then in the context of Sharia, a business or business unit that is carried out under a village-owned business entity is still minimal which moves into sharia-based business units, such as a saving and lending business unit managed by several BUMDes that do not fulfill the sharia element free from usury, if the business unit is managed based on sharia, the community does not have to borrow money from moneylenders. Then BUMDes can also take part in managing waqf which is a village asset, so far the village assets in the form of waqf land are not managed properly, many of these waqf potentials become idle land in the villages. In fact, if managed by the waqf it is a source of wealth for the people whose income can prosper the community. [15], explained that the majority of Indonesia's population is Muslim, so the implementation of BUMDes using Islamic principles is very relevant. So, from some empowerment of BUMDes, [9], [10], [11], [12], and [13] have analyzed social enterprise which is a social mission for who do business both in the city and in the village. the social form carried out is giving donations (charity) to the poor and weak groups. Whereas [11] analyzed factors influencing village credit institutions (LPD) against BUMDes.

Then research by [16], [17], [18], [2], [14], and [19], analyzed the development of rural economic potential through BUMDes to improve community welfare. . The results obtained according to [18], the existence of BUMDes does not bring significant benefits for the improvement of citizens' welfare directly. In fact, village income has increased in managing the potential of the village, but further community participation is needed in managing BUMDes. The results of this study were reinforced by L[20], who stated that BUMDes institutions were not very optimal in running their business units. Therefore according to the authors from the previous analysis there needs to be a strategic step and model for empowering BUMDes based on local potential to reach independent villages

The analytical methods used in previous studies are many qualitative ones such as [16], [18], Zulkarnaen (2016), [15], Winiagustini (2015), [9], [10] and [13], which uses SWOT structure analysis, RBV (Resource Base View), Business Analysis, Research Literature and FGD. While this study will apply several qualitative methods and use SWOT analysis.

From several studies above the development of the village's economic potential through BUMDes has been carried out in various regions. However, in the research that will be proposed to analyze BUMDes' business strategies based on local potential, so that the model that will be developed such as the type of business, sources of capital, religiosity and income is an important concern in managing BUMDes.

This research is qualitative descriptive (Sugiyono, 2006), based on the data of BUMDes in each village in the Kuala District of Nagan Raya District. For the purposes of policy formulation and the direction of village development in the future, a literature study is conducted relating to the village development program or empirical experience. The research object is 9 villages from 17 villages in the district of Kuala. This study uses primary data sources obtained directly from villages, sub-district offices, village assistants and communities. Whereas secondary data from regulatory, planning and reporting documents. The informants in this study consisted of directly and indirectly related parties, namely local government officials, administrators of village administration, such as village heads, village secretaries, heads of affairs, Chairmen / Members of the Village Consultative Body, Directors of BUMDes, elements of the community from groups the community, community institutions in the village, were obtained by purposive sampling where the researcher determined the sample based on certain decisions and considerations. Data collection techniques in this study consisted of interviews, questionnaires, focus group discussions, and document observation.

The analysis technique used is descriptive analysis. Descriptive analysis using to describe the characteristics of the variables under study includes the average analysis, the highest, lowest, and cross tables. In addition, an analysis was carried out to describe information on 
numbers and percentages or proportions. The results of the analysis are presented in the form of tables or graphs.

\section{Result and Discussion}

The approach in this study, is a qualitative method approach, to get the expected research results, the framework of the research model developed. Then to see the efficiency of the BUMDes business unit will use a SWOT analysis (Strength, Weakness, Opportunity, Threat). The variable that is used is the percentage of poverty in the district of Nagan Raya (poverty). While the independent variables are business income, PADes, business scale (Size), and business capital obtained from any source (Capital).

Poverty Measures can be measured in several ways, First Head Count Index (HCI-P) is the percentage of poor people who are under the Poverty Line (GK). Second, the Poverty Gap Index $(\mathrm{P})$ is a measure of the average gap in expenditure of each poor population against the poverty line. The higher the index value, the further the average population expenditure from the poverty line. Third. The Poverty Severity Index $(\mathrm{P})$ provides an overview of the spread of spending among the poor. The higher the index value, the higher the disparity of expenditure among the poor. The formula used to measure poverty levels is as follows:

$$
P a=1 \operatorname{aqn} \sum[i=1 z-y i z] \ldots \ldots .
$$

$\mathrm{a}=0,1,2$

$\mathrm{z}=$ poverty line line

$y i=$ Average monthly per capita expenditure of people who are below the poverty

$(\mathrm{i}=1,2, \ldots, \mathrm{q}), y<\mathrm{z}$

$\mathrm{q}=$ Number of people who are "below the poverty line."

$\mathrm{n}=$ Total population

If $\mathrm{a}=0$, the Head Count Index (P0) is obtained, if $\mathrm{a}=1$ is obtained by the poverty depth index (Poverty Gap Index-P1) and if $\mathrm{a}=2$ is called the Poverty Severity IndexP2. [6].

In the last four years the number of poor people in the case in Nagan Raya district can be seen in the table below:

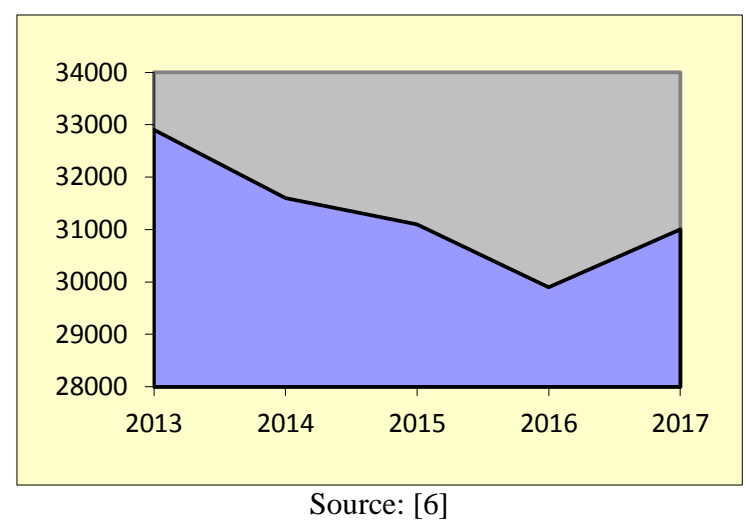

From the above curve we can note that starting in 2014 the number of poor people in Nagan Raya ranged from 32700 people, and decreased to a point of 30000 in 2016. Then the 
trend of poverty in Nagan Raya Regency increased again in 2017 reaching 31000 people. Statistically this figure shows an increase in poverty in the area, so that the poverty gap and prosperity are more open and widening.

Whereas in 2016 the percentage of poor people in 2016 amounted to 16.73 percent, a decrease of 0.35 percent compared to 2015. The percentage of poor people is more in rural areas at 19.11 percent, while in urban areas it is only 10.82 percent. (BPS, 2017).

Then with the existence of village-owned enterprises (BUMDes) can be a strategy for the village to do poverty alleviation and empowerment of the poor in the village. Besides that, the existence of businesses managed by BUMDes can also increase village income. Villages can use the PADes funds more maximally from the results of BUMDes and villages. The challenge for the village is when establishing BUMDes by involving the community, community leaders, youth elements, women's elements and other figures. In this case BUMDes can be established by the initiative of the village government and other parties that encourage. However, the challenge at a time when community participation is lacking will be an obstacle in the future. The resources or initial capital of BUMDes may come from community self-help and also the village law comes from village funds provided by the central government. Currently there are 17 villages in Kuala sub-district and not all villages are able to establish Bumdes directly initiated by the village government. At least there are currently 9 Bumdes that are classified as active, meaning that they are operating since the government has encouraged village development and empowerment programs. The source of capital for the establishment of BUMdes came from the central government so that the village easily established BUMdes without thinking about the initial capital obtained. As for some Bumdes in kuala sub-district which operate as follows:

Table 1. BUMDes Status

\begin{tabular}{clll}
\hline No & \multicolumn{1}{c}{ BUMDes } & \multicolumn{1}{c}{ Villages } & Status \\
\hline 1 & Bina Bersama & Simpang Peut & Active \\
2 & Sejahtera & Jokja & Active \\
3 & Karya Muda & Blang Bintang & Active \\
4 & Sama Rata & Ujong Patihah & Active \\
5 & Sejahtera & Lawa Batu & Active \\
6 & Maju Bersama & Purworejo & Active \\
7 & Puloe Ie & Puloe Ie & Active \\
8 & Cot Kumbang & Cot Kumbang & Active \\
9 & Blang Baroe & Blang Baroe & Active \\
\hline
\end{tabular}

From the table above there are 9 active BUMDes. This status is assessed from the results of interviews with village heads and village assistants in the district of Kuala. There are several villages in the BUMDes unit that have been active and operating, then in the middle of the trip it has deteriorated due to the activeness of the BUMdes board members. Also constrained by regulations that are difficult to understand by the public. Then among the active village students not all of them are able to utilize the local potential that exists in the village area. Local potential can be referred to as potential found in rural areas. Local potential must be assessed and processed by village communities through their respective BUMdes, because this potential is long-lived and can be utilized as long as this potential exists in rural areas. Therefore we can identify how much local potential is utilized by Bumdes in Kuala Subdistrict as follows: 
Table 2. Local Potential

\begin{tabular}{lll}
\hline \multicolumn{1}{c}{ BUMDes } & \multicolumn{1}{c}{ Business } & \multicolumn{1}{c}{ Local Potential } \\
\hline Bina Bersama & Lease \& Shop & Market \& agriculture \\
Sejahtera & Palm Oil & Plantation \\
Karya Muda & Brick Agent & Brick Industry \\
Sama Rata & Parking \& Brick Agent & Brick Industry \& market \\
Sejahtera & Palm Oil & Plantation \\
Maju Bersama & Palm Oil & Plantation \\
Puloe Ie & Savings \& loans women's & plantation \\
Cot kumbang & Broiler \& Rice field & Plantation \\
Blang Baroe & Shop \& Palm oil & Plantation \\
\hline
\end{tabular}

Regarding the local potential in the villages of the Kuala sub-district the author has identified in general that there are a lot of natural potential and potential results of the community's business. In accordance with the observations of plantation potential such as oil palm, rubber, cocoa, pulses, and others by $42 \%$, then the second largest local potential is rice fields by $30 \%$, as well as small industries such as bricks, and markets by $20 \%$. while the home industry such as tempe and tofu business is only $8 \%$ [2]. From the table above, there are several business units of BUMDes that utilize local potential and some have not been so maximal in utilizing local potential.

Like the Bumdes Bina Bersama business unit which is engaged in leasing shops in the market and the aisle, so that the management of the peut intersection can increase the village's original income (PADes), the results of the 2018 BUMDes research are able to buy village operational cars from the business results. Then at Bumdes Bina Bersama also played recordings through simple accounts that could be understood by the village community. Whereas the Prosperous and Prosperous BUMDes also utilized local potential in their BUMDes business, but the results of interviews with Lawa Batu and Jokja villages with their BUMDes business have not recorded PADes in the village cash book as income, the reason is there is no transparent management and recording of financial statements business. Businesses managed by the BUMDes Sejahtera are oil palm plantations located in the village area covering an area of 26 hectares and 3 hectares belonging to the village of Jokja. Different from BUMDes Maju with the new Purworejo village. Bumdes forwarded together only to be established early in early February 2018 by managing a 4 ha Palm Oil plantation. There are no results or revenues for Bumdes or villages.

BUMDes Puloe Ie has the potential of local plantations in rural areas. However, in Bumdes, this has not yet utilized the local potential of the village to be worked on as one of its business ventures. However, in Puloe Ie village, the women's savings and loan unit (SPP) has been running for a long time, whose income and loans have increased until 2018 at around Rp. 600 million. This program has been running since 2015 and has survived until now. Last BUMDes Sama Rata, Karya Muda and Cot Kumbang. Sama rata Bumdes Has a parking lot business unit in public hospitals, village markets and brick businesses. In Bumdes this business is developed quite a lot, considering the position and location of the Ujong Patihah Village is in the midst of community activities, so that the village is able to utilize the local potential in the region. But so far only parking lots and village markets can be managed well and develop. However, the results of the study found similar constraints with other BUMDes related to non-accountability and transparent recording. Revenues in this business unit have not been allocated to the village, such as how much profit is agreed between the manager and the village, wages for workers, as well as donations for the poor.

Furthermore, BUMDes Karya Muda in Blang Bintang village is a Bumdes that has grown from 2016. BUMDes's business activities are classified as small, only by utilizing the brick 
industry as an object. The position of BUMDes is as a supplier of brick firewood, if there is a brick factory that is ready for production Bumdes will provide firewood at a cheaper price compared to firewood obtained by the factory owner everyday. In other words BUMDes becomes agents or suppliers for brick factories in supplying their needs for firewood, sand and soil. While the income of BUMdes Karya Muda has already started recording although there is still a lack of transparency in the management of PADes for Blang bintang village.

Then BUMDes in Cot Kumbang village, it can be said that Bumdes is classified as new or young compared to other Bumdes. The business unit carried out by Bumdes is able to utilize local potential by owning rice field area assets by the village. These assets are leased to the community or involved in the system of cooperation, while the results will be divided according to the agreement of the two parties between the village and the manager of the rice fields. Then the village of Cot Kumbang also started a broiler business that cooperated with a third party but had not been very successful because of the reason for the administration of providing a place or cage for broilers that could not be provided. Although it has been running, there are obstacles to Bumdes. There is no strong regulation or legal umbrella for Cot Kumbang BUMDES and the village's original income which is still minimal cannot be distributed to villages and the poor.

Lastly, BUMDes are not well-connected with the local potential of the village area, which are brown, rubber, and others. The results of the analysis of the Bumdes writer have been active since 2016 but do not take advantage of the region's potential, but the new villages are more interested in building a shopping business that can be managed by the village or BUMDes themselves, or rented out to people who want to build their business. In 2018 Bumdes Blang Baroe began to target businesses to the oil palm plantation area with the support of capital resources from village funds. So to analyze the efficiency and effectiveness of several villages in Kuala District, we can see from the SWOT analysis.

SWOT analysis has become a useful tool in the business world. This method is an analysis that is quite good, effective and efficient as well as a tool that is fast and precise in finding and recognizing possible possibilities related to new innovations in the business world [21]. SWOT analysis is a systematic identification of various factors to formulate a company's strategy, this analysis is based on logic that can maximize strengths and opportunities, but simultaneously can minimize weaknesses and threats [15]. In applying BUMDes analysis to local potential, it certainly has several opportunities and obstacles. Therefore, a SWOT analysis of BUMDes in Kuala District is as follows:

Table 3. SWOT

\begin{tabular}{|c|c|c|c|}
\hline \multirow{4}{*}{ 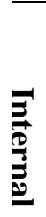 } & \multirow[t]{2}{*}{ Quadrant } & \multicolumn{2}{|c|}{ External } \\
\hline & & $\begin{array}{l}\text { Opportuni } \\
\text { ties }\end{array}$ & Threats \\
\hline & Strength & SO & ST \\
\hline & Weakness & WO & WT \\
\hline
\end{tabular}

\section{Strength.}

The strength found in Bumdes in some Kuala subdistrict villages has a lot of local potential in rural areas. Then the local potential of almost all villages used it. Besides that, the increase in Bumdes in managing business units is increasing. Then there is the awareness of the village government to develop BUMDes business in various forms. The type or scale of business owned by the village administration also varies, the greater the local potential that exists in rural areas, making Bumdes able to absorb and manage various forms of business. 


\section{Weakness}

The weaknesses experienced by BUMDes in various villages are that almost all active village heads do not have SOPs such as AD / ART which state the business direction of BUMdes and also the determination of wages for work is also not too transparent. Then the transparency and accountability of BUMDes has a routine reporting mechanism every year. The report written and given to stakeholders. The problem that arises is that residents do not understand the contents of the report, do not read it, or do not know if there is an annual report. Furthermore, there are some villages that have not implemented or started financial records well on the financial statements of BUMdes. Then the lack of community participation in supporting BUMdes business, so that Bumdes in some villages seemed less active and declining. The last issue related to Legal Standing Problems is that there are no village regulations that confirm the existence of BUMDes. BUMDes also do not have a notary deed.

\section{Opportunities}

Opportunities or opportunities that can be utilized by Bumdes are wide open access to utilize local potential in rural areas. Then there is full support from the central government through the provision of village funds and protected by village law number 6 in 2014 . Furthermore, Bumdes in Kuala sub-district can develop significantly through government support and geography conditions in Kuala Lumpur which have easy access from land like roads national and main roads. Then there are village assistants who always guide and direct Bumdes in several villages. Besides that, we need to determine the direction of the development of Bumdes in Kuala Subdistrict given that not all Bumdes businesses in several villages have been running for a long time. There are road maps that we can observe as follows:

\section{Roadmap BUMDes Growth}

\begin{tabular}{|c|c|c|}
\hline $\begin{array}{l}\text { New Bumdes } \\
\text { (Not yet } \\
\text { competitive to } \\
\text { side Cost and } \\
\text { marketting ) }\end{array}$ & & $\begin{array}{l}\text { Advance Bumdes } \\
\text { (competitive to } \\
\text { side Cost and } \\
\text { marketting) }\end{array}$ \\
\hline & $\begin{array}{l}\text { Intermediate } \\
\text { Bumdes } \\
\text { (Just competitive } \\
\text { to side Cost or } \\
\text { marketting ) }\end{array}$ & \\
\hline
\end{tabular}

For newly established campuses, the possibility of having a small chance in competing with the old Bumdes, in terms of business, costs and marketing. Then for developing village students, they only have one ability in terms of both costs and marketing. Lastly, the developed or long-standing Bumdes have been able to manage the business independently and increase the village's original income (PADes).

\section{Threats}

The criticism that will occur for the sustainability of Bumdes business is related to the original village income (PADes). If Bumdes does not operate optimally, PADes will not increase and will not affect the village. For Bumdes village, there is still no new PADes.

Then if there is no community participation, it will be difficult for BUMdes to rise in managing their business. From a fairly large business scale it will decrease to a small level so that income also decreases. Finally related to the transparency and accountability of financial 
statements. If the transparency of the accounts is not immediately corrected, the conflict in the community will continue to occur.

\section{Conclusions}

The existence of village-owned enterprises in Kual subdistrict as a village economic strengthening:

a. The village-owned business entity, which is in Kuala sub-district, is in accordance with the existing village regulations starting from the underlying legal basis, the constitution and the constituted household budget, and the organizational structure.

b. The mechanism for distributing and utilizing funds to the village bumdes in Bumdes is clear, that the initial funds owned by Bumdes come from grants provided by the village government to village-owned enterprises. who want to provide capital loans.

c. The form of the business and its development, the form of business in this village-owned business entity is very much, but over time, over time the existing body finally closed.

d. Bumdes in kuala sub-district is not all able to absorb the existing local potential. There are bumdes who are still not very active and do not have strong management.

e. Alleviating poverty through the Bumdes model there are still serious obstacles, there are still many villages that have not been able to alleviate poverty experienced by the community.

f. There is no transparency and accountability to the financial statements in Bumdes.

\section{Acknowledgements}

The researcher would like to thank for the Ministry of Research, technology and higher education of the republic of Indonesia, because this research is part of the core research that the researcher did, Institute for Research and Community Service (LPPM) University of Serambi Mekkah Aceh which has become a forum for researchers, to the Partner Research Team from University of Malikussaleh Aceh who became a partner in this research, and to all resource, BPM, BPS and related agencies that support the success of this research.

\section{References}

[1] A. R. Ramly, W. Wahyuddin, J. Mursyida, and Mawardati, "IMPLEMENTASI KEBIJAKAN DANA DESA DALAM PENGELOLAAN DAN PENINGKATAN POTENSI DESA (Studi Kasus Kec Kuala Kabupaten Nagan Raya),” Pros. Semin. Nas. USM, vol. 1, no. 1, 2017.

[2] A. R. Ramly and J. Mursyida, "The Model and Strategy Improved of Empowering Economic Community Based on Village Fund Allocation: Empirical Study in Kuala Sub District, Nagan Raya District," Adv. Sci. Lett., vol. 24, no. 1, pp. 362-364, 2018.

[3] Z. Ridlwan, "Urgensi Badan Usaha Milik Desa(Bumdes) Dalam Pembangun Perekonomian Desa," Ilmu Huk., vol. 8, no. 3, pp. 424-440, 2014.

[4] C. B. Ramadana, H. Ribawanto, and Suwondo, "Keberadaan Badan Usaha Milik Desa (BUMDes) sebagai Penguat Ekonomi Desa (Studi di Desa Landungsari, Kecamatan Dau, Kabupaten Malang)," J. Adm. Publik, vol. 53, no. 9, pp. 1689-1699, 2013.

[5] A. S. K. Dewi, "Peranan Badan Usaha milik Desa (BUMDes) Sebagai Upaya Dalam Meningkatkan Pendapatan Asli Desa (PADes) Serta Menumbuhkan Perekonomian Desa," J. Rural Develpment, vol. V, no. 1, pp. 1-14, 2014. 
[6] Badan Pusat Statistik, "No Title," 2018

[7] K. Natsuda, K. Igusa, A. Wiboonpongse, and J. Thoburn, "One Village One Product-Rural Development Strategy In Asia: The Case Of Otop In Thailand," Can. J. Dev. Stud. Can. D'études Du Développement, vol. 33, no. 3, pp. 369-385, 2012.

[8] A. Park and S. Wang, ") Community-Based Development And Poverty Alleviation: An Evaluation Of China's Poor Village Investment Program," J. Public Econ., vol. 94, no. 9-10, pp. 790-799, 2010.

[9] M. T. Hackett, "Challenging Social Enterprise Debates in Bangladesh," Soc. Enterp. J., vol. 6, no. 3, pp. 210-224, 2015.

[10] D. Akella and N. Eid, "Social enterprises in Palestine: a critical analysis," J. Enterprising Communities People Places Glob. Econ., 2018.

[11] N. L. P. Wiagustini, "Partnership Strategy of Village Owned Enterprises ( Village Credit Institutions and Village Markets ) in Denpasar City, Indonesia," Int. J. Econ. Commer. Manag., vol. III, no. 4, pp. 1-20, 2015.

[12] G. Galera and C. Borzaga, "Social enterprise: An international overview of its conceptual evolution and legal implementation," Soc. Enterp. J., vol. 5, no. 3, pp. 210-228, 2009.

[13] M. MacDonald and C. Howorth, "Roots of Social Enterprise: Entrepreneurial Philanthropy," Soc. Enterp. J., vol. 14, no. 1, p. .4-21, 2018.

[14] V. Q. Chintary and A. W. Lestar, "Peran Pemerintah Desa Dalam Mengelola Badan Usaha Milik Desa ( Bumdes )," J. Ilmu Sos. dan Ilmu Polit., vol. 5, no. 2, pp. 59-63, 2016.

[15] Bambang, "Implemetasi Badan Usaha Milik Desa Berbasis Ekonomi Islam: Suatu Kajian Elementer," J. Iqtisaduna, vol. 3, no. 2, pp. 109-131, 2017.

[16] A. Suriadi, Rudjiman, K. Mahalli, N. Achmad, and I. Muda, "The Applicative Model Of The Village-Owned Enterprises (BUM Desa) Development In North Sumatera," IOSR J. Econ. Financ., vol. 3, no. 12, pp. 48-62, 2015.

[17] R. Hardijono, Y. A. Maryunani, and Ananda, CF, "Economic Independence of The Village Through Institutional Village Enterprises (BUMDes)," IOSR J. Econ. Financ., vol. 3, no. 2, pp. 21-30, 2014.

[18] M. R. R. S. Anggraeni, "Peranan Badan Usaha Milik Desa (Bumdes) Pada Kesejahteraan Masyarakat Pedesaan Studi Pada Bumdes Di Gunung Kidul, Yogyakarta,” Modus, vol. 28, no. 2, pp. 155-167, 2016.

[19] R. M. Zulkarnaen, "Pengembangan Potensi Ekonomi Desa Melalui Badan Usaha Milik Desa (BUMDes) Pondok Salam Kabupaten Purwakarta,” J. Apl. Iptek untuk Masy., vol. 5, no. 1, pp. 1-4, 2016.

[20] T. Lestari, "Peran Pemerintahan Desa Terhadap Pembangunan Perekonomian Melalui Badan Usaha Milik Desa (Bumdes) Mitra Usaha Mulya Di Desa Marga Mulya Kecamatan Rambah Samo Kabupaten Rokan Hulu," vol. 4, no. 1, pp. 1-8, 2017.

[21] In. Soesilo, Manajemen Stratejik di Sektor Publik (Pendekatan Praktis), 2nd ed. Jakarta: Universitas Indonesia, 2002. 